\title{
"Top ten": another alert on the prescription of proton-pump inhibitors (PPIs) for the elderly
}

\author{
Maria Elisa Gonzalez Manso $0^{\mathbf{1}, 2}$ \\ Henrique Souza Barros de Oliveira²
}

1. Pontifical Catholic University of São Paulo (PUC-SP), Rua Monte Alegre, 984, Perdizes - São Paulo - SP CEP: 05014-901. 2. Faculty of Medicine, University Center São Camilo (CUSC-SP), Av. Nazaré, 1501 - Ipiranga, São Paulo - SP, 04263-200.

It is estimated that around $30 \%$ of all reasons why elderly individuals seek health services are associated with Adverse Drug Events (ADE) and these are more frequent when the drug used is considered unfit for use in elderly individuals. Potentially Inappropriate Medications (PIM) are drugs whose risk of causing an adverse reaction is greater than the benefits provided or that have few scientific evidence on their effectiveness. Given this scenario, researchers from different regions of the world have proposed to draw up lists, criteria and/or consensus of Potentially Inappropriate Medications (PIM) for use in the elderly. The United States, Canada, Germany, Ireland, Australia, England, France, Norway, South Korea, and Brasil have created lists of PIM. ${ }^{1}$

In a study recently published in the Brazilian Magazine of Sciences on Human Aging (RBCEH) ${ }^{2}$, in the context of Pharmaceutical Sciences, 5,995 drug prescriptions made to 1,428 elderly individuals suffering from chronic diseases linked to the supplementary health sector were analyzed. The study, in an exploratory and descriptive level, applied the Beers Criteria of the American Geriatrics Society, 2015 version, and tracked 1,220 (20.3\%) prescriptions of PIM. Among these potentially inappropriate prescriptions, proton pump inhibitors (PPI) were the most prevalent $(39.4 \%)^{2}$
The Brazilian Society of Gerontology and Geriatrics (SBGG) in partnership with Choosing Wisley Brasil drew up the "Top Ten" recommendations and officially presented them at the XXI Brazilian Congress of Geriatrics and Gerontology (CBGG), which took place in June 2018 in Rio de Janeiro/RJ. It is a list of ten recommendations based on scientific evidence for sensible choices on elderly health care. Seven of the list recommendations are directed at pharmacotherapy in elderly patients. In particular, the fifth recommendation suggests health professionals do not maintain a continuous prescription of PPI for the elderly patients for a period longer than eight weeks; if it is prescribed, then there should be a clear acknowledgment its recommendation and the lowest effective dose should be used. ${ }^{3}$

The PPI (represented by the omeprazole, lansoprazole, pantoprazole, rabeprazole, esomeprazole, and tenatoprazole) act quickly and highly specifically on the parietal cells of the stomach to treat gastrointestinal disorders. They are capable of acting on the $\mathrm{H}^{+} / \mathrm{K}^{+}$ATPase enzyme (proton pump), inhibiting the final step of the formation of gastric acid, both from basal and stimulated secretion, regardless of the stimulus. When achieved through the liver, its metabolism occurs via the cytochrome $\mathrm{P} 450$ system (specifically in the CYP2C19 isoenzyme and, to a less- 
er extent, the CYP3A4) and is subsequently excreted mostly through the urine. All of these processes are impaired in elderly individuals as a result of changes caused by the aging process. ${ }^{4}$

In another study published in 2018, Cheung et al. ${ }^{5}$ showed that the continuous use of a PPI in individuals with an active infection by Helicobacter pylori or with successful eradication is associated with a significantly increased risk of gastric cancer. In addition, PPIs are potentially interactive with other inhibitors, enzymatic inductors, and foods. It is also known that there is a potential risk of gastric atrophy, disability in the absorption of nutrients, osteopenia, osteoporosis and fractures, dementia, pneumonia, renal injury, diarrhea (of bacterial origin caused by Clostridium difficile) and possible hydroelectrolytic disorders. ${ }^{2.6}$

Despite the scientific evidence suggesting the non-prescription of long-term PPI (for longer than eight weeks) in the elderly, the Top Ten recommendations by SBGG stresses, once more, the importance of reviewing all medications in use and the recommendation for the non-chronic use of PPI. It is worth noting also that PPIs are drugs considered exempt from prescription (over-the-counter - OTC) by ANVISA, which facilitates self-medication by the elderly - a frequent practice among this age group and increases the risk for adverse clinical outcomes. This scenario favors the emergence of ADE and, consecutively, of the prescription cascade (or cascade iatrogenesis).

A good doctor-patient relationship with the elderly, in which they are advised about the risks of self-medication, can improve this scenario, in addition of the wide dissemination of the Top Ten recommendations and effective public policies aimed at the constant updating of professionals and the Brazilian population.

\section{Conflicts of interest}

The authors declare there are no conflicts of interest associated with this publication.

\section{REFERENCES}

1. Nam YS, Han JS, Kim JY, Bae WK, Lee K. Prescription of potentially inappropriate medication in Korean older adults based on 2012 Beers Criteria: a cross-sectional population based study. BMC Geriatrics. 2016;16:118.

2. Oliveira HSB, Sousa JRP, Donis ACG, Manso MEG. Utilização dos critérios de Beers para avaliação das prescrições em idosos portadores de doenças crônicas vinculados a um plano de saúde. RBCEH. 2017;14(3):242-51.

3. Sociedade Brasileira de Geriatria e Gerontologia, SBGG. CBGG 2018 : SBGG divulga recomendações sobre escolhas sensatas em saúde em parceria com Choosing Wisely Brasil [Internet]. Sociedade Brasileira de Geriatria e Gerontologia; 2018 [cited 2018 dez 10]. Available from: https:// sbgg.org.br/cbgg-2018-sbgg-divulgarecomendacoes-sobre-escolhas-sensatas-em-saude-em-parceriacom-choosing-wisely-brasil/
4. Eurofarma. Omeprazol sódico, bula para profissional da saúde, pó liófilo para solução injetável, 40 mg [Internet]. Eurofarma. [cited 2018 dez 10]. Available from: https://www.eurofarma.com.br/wp-content/uploads/2016/09/Bula_Omeprazol_S\%C3\%83\%C2\%B3dico_Profissional. pdf

5. Cheung KS, Chan EW, Wong AYS, Chen L, Wong ICK, Leung WK. Longterm proton pump inhibitors and risk of gastric cancer development after treatment for Helicobacter pylori: a population-based study. Gut. 2018;67(1):28-35

6. Oliveira MG, Amorim WW, Oliveira CRB, Coqueiro HL, Gusmão LC, Passos LC. Consenso brasileiro de medicamentos potencialmente inapropriados para idosos. Geriatr Gerontol Aging. 2017;10(4):168-81. 